\title{
ANALISIS FINANSIAL AGROFORESTRI KAKAO DI LAHAN HUTAN NEGARA DAN LAHAN MILIK
}

\author{
Financial Analysis of Cocoa Agroforestry in State Forest Land and Private Land \\ Indra Gumay Febryano
}

\begin{abstract}
The cultivation of cocoa (Theobroma cacao) has been an important driver of tropical deforestation globally. Efforts to reverse this trend are focusing on the reintroduction of shade trees to cocoa plantations. Shade trees are valuable in enhancing biophysical conditions on cocoa fields and contribute to biodiversity and product diversification for smallholder producers. The aim of this study was to compare financial analysis of cocoa agroforestry between in state forest land and private land. Financial analysis was undertaken to assess its economic viability. Input-output data were collected from farmer by interview and participant observation. A discounted cash flow analysis was carried out to estimate the benefit-cost $(B / C)$ ratio, net present value (NPV), internal rate of return (IRR) at $6,4 \%$ discount rate. The results showed that the main combination of planting pattern that consist of cacao and banana (in state forest land), cacao and petai, cacao and durian (in private land) were financially feasible; the largest contribution was given by cacao at all planting patterns based on farmer household revenue structure.
\end{abstract}

Key words: Financial analysis, cocoa, agroforestry, land tenure security

\section{PENDAHULUAN}

Penanaman kakao (Theobroma cacao) merupakan salah satu faktor penting yang mendorong deforestasi hutan tropis secara global. Usaha-usaha yang dilakukan untuk mengembalikan fungsi hutan tropis tersebut, difokuskan dengan mengintroduksi pohon-pohon naungan pada perkebunan kakao. Kakao yang dinaungi pohon lebih menguntungkan dibandingkan dengan yang tidak dinaungi, tetapi hasil awal dan puncaknya lebih sedikit; dimana pohon-pohon naungan bermanfaat meningkatkan kondisi biofisik kakao dan memberi kontribusi untuk keanekaragaman hayati dan diversifikasi produk untuk petani kecil (Obiri et al. 2007). Nair (1993) menjelaskan bahwa kakao dapat dikombinasikan dengan tanaman kehutanan dalam konsep agroforestri; sehingga di satu sisi masyarakat dapat mendapatkan hasilnya dan di sisi lain konservasi tanah tetap terjaga. Hal ini didukung oleh penelitian Iswandi et al. (1996) di Sulawesi Tenggara bahwa petani mengusahakan kombinasi kakao dengan langsat dan kelapa; serta kombinasi kakao dengan durian dan kelapa.

Beberapa hasil penelitian menunjukkan bahwa tanaman yang tumbuh di bawah naungan pohon, menyediakan petani sejumlah keuntungan dibandingkan tanaman yang tumbuh di bawah sinar matahari secara penuh. Keuntungan tersebut antara lain memelihara produktivitas untuk periode waktu yang lebih panjang, mengurangi serangan hama dan penyakit, dan mengurangi kebutuhan modal dan tenaga kerja, seperti pupuk, insektisida, dan penyiangan (Purseglove 1968, Young 1989). Keuntungan berikutnya adalah hasil-hasil lainnya, seperti buah-buahan, serat, obat-obatan, dan kayu, yang dapat dipanen jika dibutuhkan ketika harga pasar kakao dan kopi sedang rendah. Petani juga dapat menjalankan aktivitas pertanian lainnya, termasuk menghasilkan tanaman pangan pada sebagian lahan yang tidak menggunakan sistem teknis yang melibatkan bahan-bahan yang harus dibeli, seperti benih, pupuk, pestisida, dan lain-lain, sehingga kurang dipengaruhi fluktuasi harga pasar (Collier et al. 1994, Thrupp 1998). Tanaman yang tumbuh di bawah naungan pohon cenderung untuk ditanam petani kecil yang kekurangan modal untuk mengkonversi sistem pertaniannya menjadi lebih teknis, seperti tanaman yang tumbuh di bawah sinar matahari secara penuh. Terakhir, tanaman yang tumbuh di bawah naungan pohon menyediakan biodiversitas dan fungsi ekosistem yang menguntungkan petani secara keseluruhan (Lenne dan Wood 1999, Perfecto et al.1996). 
Walaupun beberapa hasil penelitian di atas menunjukkan keuntungan-keuntungan pengelolaan kakao yang dikelola secara agroforestri, tetapi masih banyak masyarakat yang menanam kakao secara monokultur tanpa dikombinasikan dengan tanaman-tanaman pohon, terutama di lahan hutan negara. Hal ini sangat penting, karena banyak program penanaman pohon yang dilakukan oleh pemerintah di lahan hutan negara yang digarap oleh masyarakat sering menemui kegagalan, karena masyarakat enggan untuk menanam bibit tanaman yang diberikan oleh pemerintah dan lebih memilih jenis tanaman dan pola tanam tertentu; sebaliknya, penanaman pohon di lahan milik lebih banyak yang berhasil. Suharjito (2002) menjelaskan bahwa beberapa penelitian sosial, ekonomi dan budaya yang telah dilakukan, menggambarkan hubungan yang sangat erat antara sistem penguasaan lahan (land tenure system) dengan praktek agroforestri.

Penelitian ini bertujuan untuk membandingkan kelayakan finansial agroforestri kakao yang diusahakan oleh masyarakat pada sistem penguasaan lahan yang berbeda, yaitu antara yang berlokasi di lahan hutan negara dan lahan milik. Hasil analisis akan bermanfaat bagi berbagai pihak, seperti masyarakat, Dinas Kehutanan, universitas, lembaga swadaya masyarakat, dan lain-lain, yang bermaksud mengembangkan kehutanan masyarakat.

\section{BAHAN DAN METODE}

\section{Lokasi dan Waktu Penelitian}

Penelitian dilaksanakan di dua lokasi yaitu: (1) di lahan hutan negara yang berada di Tahura Wan Abdul Rahman (Tahura WAR), di mana lahan tersebut berbatasan langsung dengan Desa Sungai Langka, dan (2) di lahan milik yang berada di Desa Sungai Langka, Kecamatan Gedong Tataan, Kabupaten Pesawaran, Propinsi Lampung. Penelitian ini dilakukan selama 3 bulan, yaitu pada bulan Maret-Mei 2008.

\section{Metode Pengumpulan Data}

Pengumpulan data dilakukan dengan melakukan wawancara dan observasi partisipan. Pemilihan sampel dilakukan secara purposive sampling, di mana jumlah informan kunci adalah sebanyak 22 orang petani yang berusaha di lahan hutan negara, dan 18 orang petani yang berusaha di lahan milik.

\section{Analisis Data}

\section{Analisis Finansial}

Analisis ini dilakukan untuk mengetahui kelayakan pengusahaan lahan hutan negara dan lahan milik dengan jenis tanaman dan pola tanam yang dipilih oleh petani. Kriteria yang digunakan adalah Net Present Value (NPV), Benefit Cost Ratio (BCR), dan Internal Rate of Return (IRR) (Tabel 1). Jika nilai NPV $>0, B C R>1$, dan IRR > i, maka pengusahaan lahan, baik di lahan hutan negara maupun lahan milik, dianggap layak.

\section{Struktur Pendapatan Rumah Tangga}

Untuk mengetahui kontribusi setiap sumber pendapatan rumah tangga petani pada setiap pola tanam baik di lahan hutan negara maupun lahan milik, dilakukan dengan cara melihat struktur pendapatan rumah tangga petani selama jangka waktu pengusahaan lahan.

Table 1. Indicator using in calculation financial analysis

\begin{tabular}{ccc}
\hline Indikator & Rumus & Kriteria keputusan \\
\hline $\mathrm{NPV}$ & $N P V=\sum_{t=1}^{n} \frac{(B t-C t)}{(1+i)^{t}}$ & $\mathrm{NPV}>0$ \\
$\mathrm{BCR}$ & $B C R=\frac{\sum_{t=1}^{n} \frac{B t}{\sum_{t=1}^{n} \frac{C t}{(1+i)^{t}}}}{\mathrm{BCR}>1}$ \\
$\mathrm{IRR}$ & $N P V=\sum_{t=1}^{n} \frac{(B t-C t)}{(1+i)^{t}}=0$ & IRR $>\mathrm{i}$
\end{tabular}

$\mathrm{Bt}=$ penerimaan kotor petani pada tahun $\mathrm{t}, \mathrm{Ct}=$ biaya kotor usaha tani pada tahun $\mathrm{t}, \mathrm{n}=$ lama rotasi, $\mathrm{t}=$ periode produksi, $\mathrm{i}=$ suku bunga 
Table 2. Financial analysis of land tenure systems

\begin{tabular}{cccc}
\hline \multirow{2}{*}{ Kriteria penilaian } & \multicolumn{3}{c}{ Pola tanam } \\
\cline { 2 - 4 } & $\begin{array}{c}\text { Kakao+pisang } \\
\text { di lahan hutan negara }\end{array}$ & $\begin{array}{c}\text { Kakao+petai } \\
\text { di lahan milik }\end{array}$ & $\begin{array}{c}\text { Kakao+durian } \\
\text { di lahan milik }\end{array}$ \\
\hline NPV & Rp 17.452.336,56 & Rp 41.860.069,85 & Rp 42.864.090,38 \\
BCR & 1,32 & 1,77 & 1,79 \\
IRR & $23 \%$ & $27 \%$ & $28 \%$ \\
\hline
\end{tabular}

\section{HASIL DAN PEMBAHASAN}

Perhitungan analisis finansial dilakukan berdasarkan data-data harga yang diambil pada bulan Maret-Mei 2008, dengan tingkat suku bunga rata-rata adalah $6,4 \%$. Jangka waktu pengusahaan lahan hutan negara dan lahan milik diasumsikan selama 20 tahun, karena disesuaikan dengan umur ekonomis kakao sebagai tanaman utama yang ditanam oleh petani (Siregar et al. 2007; Iswandi et al. 1996). Asumsi ini didukung oleh hasil penelitian Obiri et al. (2007), yang menjelaskan bahwa umur rotasi ekonomis kakao hanya 18 tahun untuk kakao yang tidak mendapat naungan dan 29 tahun untuk yang mendapat naungan.

Kombinasi utama pola tanam yang diusahakan sebagian besar petani di lahan hutan negara adalah kakao+pisang, sementara di lahan milik adalah kakao+petai, serta kakao+durian (simbol + menunjukkan "ditanam pada lahan yang sama dengan"). Dari hasil penilaian NPV, BCR, dan IRR, terlihat bahwa pola tanam kakao+pisang di lahan hutan negara, dan kakao+petai serta kakao+durian di lahan milik layak untuk diusahakan (Tabel 2).

Nilai NPV untuk pola tanam kakao+petai dan kakao+durian lebih tinggi dibandingkan dengan kakao+pisang. Hal ini menunjukkan bahwa pola tanam kakao+durian dan kakao+petai lebih menguntungkan secara finansial dibandingkan pola tanam kakao+pisang. Selisih nilai NPV yang cukup besar antara pola tanam kakao+pisang dengan pola tanam kakao+petai dan kakao+durian karena nilai lahan di lahan hutan negara tidak ikut diperhitungkan, sementara di lahan milik diperhitungkan. Nilai lahan yang berlaku di lahan milik pada saat penelitian dilakukan adalah $\mathrm{Rp}$ 100.000.000/ha (lahan dengan tanaman) dan Rp 70.000.000/ha (lahan kosong); sementara di lahan hutan negara adalah Rp 40.000.000/ha (lahan dengan tanaman) dan $\mathrm{Rp} 10.000 .000$ (lahan kosong). Nilai di lahan hutan negara merupakan harga di bawah tangan; dimana harga tersebut sebenarnya merupakan harga yang berlaku untuk mengambil alih hak garap dari petani lainnya, dan bukan harga lahannya.

Bila dilihat dari struktur pendapatan rumah tangga petani pada setiap pola tanam selama 20 tahun (sesuai dengan asumsi yang digunakan pada analisis finansial), pola tanam kakao+petai dan kakao+durian ternyata lebih baik dibandingkan pola tanam kakao+pisang (Gambar 1). Kakao memberikan kontribusi terbesar pada setiap pola tanam. Pisang hanya memberikan kontribusi pada tahun-tahun awal, karena pisang tidak dapat tumbuh lagi ketika kakao tertutup rapat pada umur 9 tahun; tetapi pisang menjadi sumber pendapatan utama ketika kakao belum berproduksi. Sementara petai dan durian memberikan kontribusi yang cukup besar dan terus mengalami peningkatan, ketika produktivitas kakao mulai menurun. Pisang, petai dan durian memberikan kontribusi yang lebih kecil dibandingkan kakao, karena tanaman tersebut hanyalah tanaman sekunder dan bukan ditanam oleh petani sebagai tanaman utama. Dalam satu hektar, rata-rata terdapat sekitar 833 batang kakao yang dikombinasikan dengan pisang rata-rata sebanyak 208 rumpun (di lahan hutan negara), serta tanaman durian dan petai rata-rata sebanyak 15 batang (di lahan milik).

Walaupun pola tanam kakao+durian dan kakao+petai lebih menguntungkan secara finansial dibandingkan pola tanam kakao+pisang, tetapi petani yang berusaha di lahan hutan negara lebih memilih pola tanam kakao+pisang. Dalam kasus ini, konsep resiko dan ketidakpastian lebih ditekankan kepada tidak adanya keamanan penguasaan lahan di lahan hutan negara, sehingga petani lebih cenderung berorientasi jangka pendek dengan menanam jenis tanaman yang cepat menghasilkan seperti kakao dan pisang; dan tidak menanam tanaman jangka panjang seperti petai atau durian (seperti di lahan milik). Walaupun begitu saat ini ada beberapa petani baik di lahan hutan negara maupun di lahan milik yang telah mencoba melakukan diversifikasi jenis tanamannya dengan mengkombinasikan 
kakao sebagai tanaman utama dengan karet, pala, petai, durian, cengkeh, kelapa, dan jati sebagai tanaman sekunder. Hal ini tidak terlepas dari mulai menurunnya produktivitas kakao yang mulai banyak terkena penyakit. Diversifikasi jenis tanaman yang dilakukan oleh beberapa petani ini dapat mengurangi resiko, seperti hama dan penyakit, serta ketidakstabilan harga produkproduk yang dipanen.
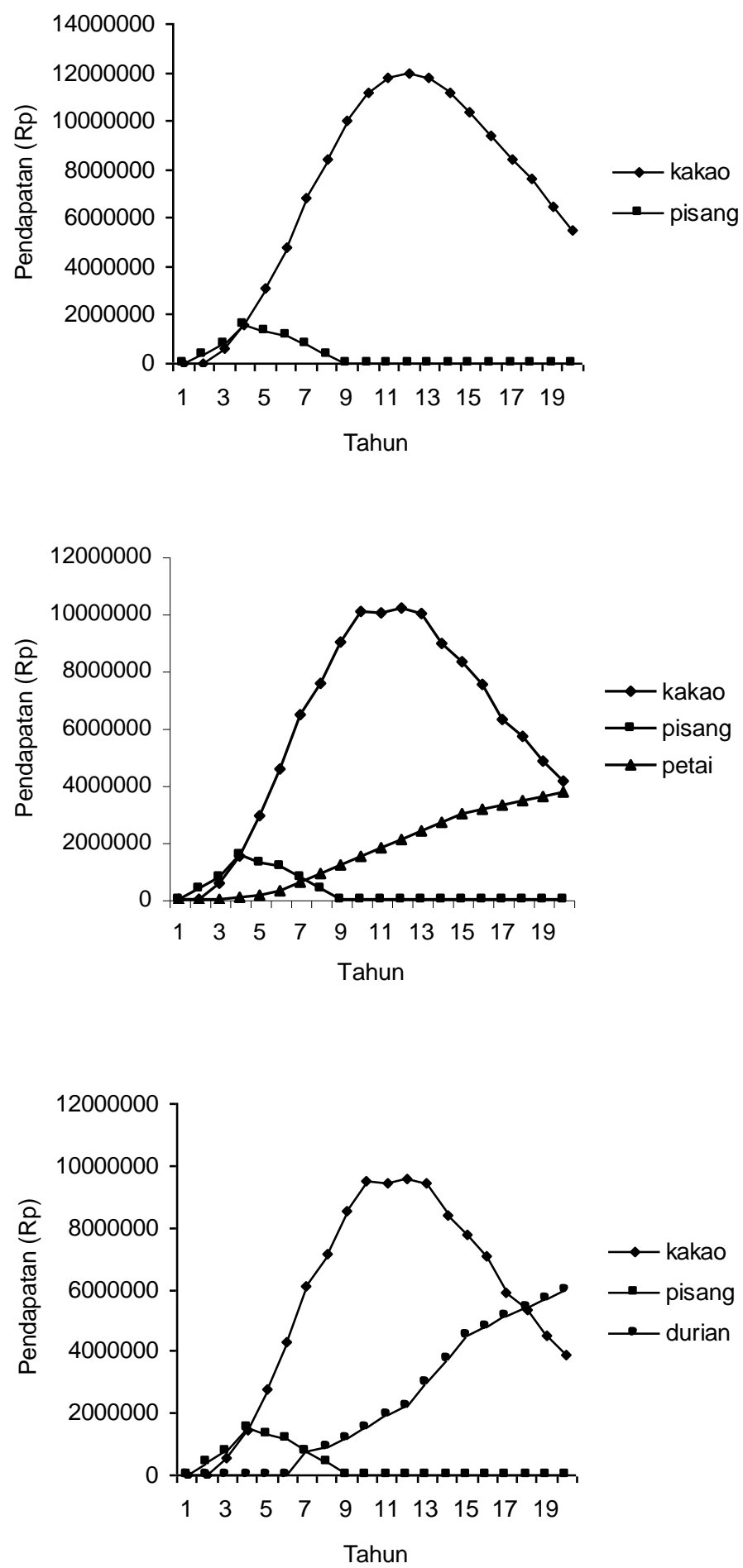

Figure 1. Household revenue structures 
Tidak adanya keamanan penguasaan lahan, yang merupakan hak untuk memperoleh manfaat hasil hutan, sangat berhubungan dengan sejarah pengelolaan lahan di desa tersebut. Desa Sungai Langka dibuka pada awal tahun 1900-an oleh transmigran yang berasal dari daerah Jawa Tengah dan Jawa Timur. Pada tahun 1950-an, penduduk mulai menggarap lahan hutan negara yang berbatasan langsung dengan desa di Taman Hutan Rakyat Wan Abdul Rahman (dahulu Hutan Lindung Register 19 Gunung Betung). Terdapat tiga pemukiman di lahan hutan negara pada saat itu, yaitu Kampung Karawang, Gunung Wetan dan Batu Lapis. Jenis tanaman utama yang ditanam oleh penduduk di lahan hutan negara pada saat itu adalah kopi. Pemerintah mengeluarkan kebijakan untuk mereboisasi lahan hutan negara pada tahun 1982-1985, dengan memindahkan penduduk melalui program transmigrasi lokal ke daerah Mesuji (Kabupaten Tulang Bawang) dan Pakuan Ratu (Kabupaten Way Kanan). Program reboisasi ini menggunakan jenis-jenis tanaman seperti sonokeling, lamtoro dan kaliandra. Pengelolaan kebun-kebun yang berada di lahan hutan negara, yang didominasi oleh kopi, selanjutnya diserahkan kepada penduduk yang tinggal di Desa Sungai Langka (sebagian besar dengan cara memberi ganti rugi atas tanaman dan biaya/jasa perawatan kebun yang sudah dikeluarkan). Masyarakat kembali menggarap lahan hutan negara, pada tahun 1998 saat tumbangnya rezim Orde Baru. Masyarakat meneres dan menebang tanaman hasil reboisasi yang sudah menutupi lahan dengan rapat, dan selanjutnya tanaman kopi mulai diganti dengan kakao. Pada tahun 2002, kakao mulai ditanam secara meluas di lahan hutan negara. Sementara di lahan milik, sama seperti di lahan hutan negara, penanaman kopi dilakukan sekitar tahun 1950-an sampai 1960-an. Lalu kopi diganti dengan cengkeh pada tahun 1970-an. Pada akhir tahun 1980-an ketika cengkeh mati secara serentak karena terkena penyakit, kakao mulai ditanam oleh petani dan ditanam secara meluas pada awal tahun 1990. Vanili sempat juga diusahakan oleh sebagian penduduk untuk menggantikan cengkeh, tetapi tanaman tersebut banyak mengalami kegagalan akibat kematian karena musim kemarau yang berkepanjangan.

Pelibatan masyarakat dalam sistem pengelolaan hutan negara secara formal baru dimulai ketika Departemen Kehutanan meluncurkan program Hutan Kemasyarakatan (HKm) pada akhir tahun 1990-an yang memberi peluang kepada masyarakat setempat untuk mengelola lahan hutan negara. Kelompok tani yang bernama Kelompok Pengelola dan Pelestari Hutan (KPPH) Wana Makmur di Desa Sungai Langka dibentuk pada tanggal 13 Februari 2000 dengan maksud untuk memperoleh ijin pengelolaan $\mathrm{HKm}$, walaupun sampai dengan saat ini, KPPH Wana Makmur belum juga mendapatkan ijin tersebut. Jumlah anggota yang terdaftar di KPPH Wana Wakmur sebanyak 235 anggota, dengan jumlah lahan garapan di lahan hutan negara di Tahura WAR sekitar 200 hektar.

Jangka waktu pengelolaan lahan hutan negara selama jangka waktu 5 (lima) tahun, sesuai dengan SK Menteri Kehutanan No. 31/KptsII/2001, juga merupakan salah satu faktor yang membuat tidak adanya keamanan penguasaan lahan. Selain itu kurangnya pembinaan dan sosialisasi $\mathrm{HKm}$ dari Dinas Kehutanan menimbulkan resiko dan ketidakpastian bagi masyarakat untuk mengelola lahan hutan negara, sehingga pada akhirnya memberikan kontribusi kegagalan kegiatan konservasi di lahan hutan negara. Secara de facto kontrol petani atas lahan hutan negara yang digarap lebih kuat dibandingkan kontrol pemerintah, walaupun mereka menyadari bahwa lahan yang mereka garap adalah lahan hutan negara. Oleh karena itu diperlukan kebijakan pemerintah yang berciri win-win solution, di satu sisi dapat menyejahterakan masyarakat sekitar hutan negara dan di sisi lain konservasi kawasan hutan negara tetap berjalan.

Walaupun saat ini telah ada kebijakan baru dari pemerintah, tetapi kelembagaan kelompok petani pengelola hutan masih belum berkembang dengan baik. Salah satu hal yang sangat penting adalah membangun kembali kepercayaan masyarakat terhadap pemerintah, khususnya pihak kehutanan, dengan memberikan jaminan yang lebih pasti untuk memperoleh manfaat hasil hutan. Sebagian besar petani menyatakan bahwa mereka merasa trauma akibat pengusiran oleh pemerintah terhadap penduduk dari lahan hutan negara pada tahun 1982-1985, dimana pada saat itu petani tidak dapat menikmati hasil jerih payahnya.

Berbagai jenis program reboisasi yang dilakukan pemerintah setelah tahun 1998, khususnya di kawasan Tahura WAR, seperti Gerakan Nasional Rehabilitasi Hutan dan Lahan (GNRHL) dan lain-lain, ternyata tidak berjalan dengan mulus. Petani enggan menanam jenis-jenis tanaman yang diberikan oleh pemerintah walaupun merupakan jenis-jenis tanaman serbaguna, seperti 
karet, durian, kemiri, tangkil, petai, jambe, medang dan cempaka. Petani masih lebih menyukai menanam kakao sebagai tanaman utama yang dikombinasikan dengan pisang sebagai tanaman sekunder di lahan hutan negara. Dinas Kehutanan, dalam hal ini Unit Pelaksana Teknis Daerah (UPTD) Tahura WAR, seharusnya mengakomodasi jenis-jenis tanaman yang dipilih oleh petani, yaitu kakao sebagai tanaman utama dan mengkombinasikannya dengan tanaman kehutanan yang dipilih oleh petani. Karena bila dilihat di lahan milik yang berada di Desa Sungai langka, ternyata kakao dapat tumbuh dan berproduksi dengan baik walaupun dikombinasikan dengan tanaman pohon lain, seperti petai, durian, kelapa atau jati.

\section{KESIMPULAN DAN SARAN}

\section{Kesimpulan}

Jenis tanaman utama yang dipilih oleh petani adalah kakao; dengan kombinasi utama pola tanam kakao+pisang di lahan hutan negara, dan kakao+petai serta kakao+durian di lahan milik. Ketiga pola tanam tersebut layak untuk diusahakan berdasarkan hasil analisis finansial. Nilai NPV, $B C R$, dan IRR berturut-turut sebesar Rp 17.452.336,56; 1,32; dan 23\% (pola tanam kakao+pisang), Rp 41.860.069,85; 1,77; dan 27\% (pola tanam kakao+petai), dan Rp 42.864.090,38; 1,79; dan 28\% (pola tanam kakao+durian).

Pola tanam kakao+durian dan kakao+petai lebih menguntungkan secara finansial dibandingkan pola tanam kakao+pisang, tetapi petani yang berusaha di lahan hutan negara lebih memilih pola tanam kakao+pisang; karena tidak adanya keamanan penguasaan lahan di lahan hutan negara. Sementara berdasarkan struktur pendapatan rumah tangga, pola tanam kakao+petai dan kakao+durian lebih baik dibandingkan pola tanam kakao+pisang.

\section{Saran}

Dinas Kehutanan (Unit Pelaksana Teknis Daerah Tahura WAR) dapat mengembangkan potensi pengetahuan dan keinginan petani dalam membudidayakan tanaman perkebunan yang dikombinasikan dengan tanaman keras/pohon di lahan milik, dengan cara memanfaatkan pengetahuan tersebut dan memberikan jaminan agar petani dapat memperoleh manfaat dari tanaman yang ditanam di lahan hutan negara. Pihak UPTD Tahura WAR sebaiknya mengakomodasi jenis-jenis tanaman yang telah dipilih dan ditanam oleh petani di lahan hutan negara dan mengkombinasikannya dengan jenisjenis tanaman kehutanan yang sesuai dengan kebutuhan petani setempat. Kepercayaan masyarakat harus dibangun kembali oleh Dinas Kehutanan dan pembinaan serta sosialisasi kepada masyarakat yang berada di dalam dan sekitar kawasan hutan harus ditingkatkan.

\section{DAFTAR PUSTAKA}

Collier, G., D. Mountjoy, and R. Nigh. 1994. Peasant Agriculture and Global Change. Bio Science, 44: 398-407.

Iswandi, M.R., A. Anwar, B.D. Nasendi, dan H. Siregar. 1996. Analisis Ekonomi dan Kelembagaan Hutan Rakyat Sistem Agroforestri Kombinasi Jenis Pohon Serbaguna dan Kakao: Suatu Studi Kasus di Propinsi Sulawesi Tenggara. Pusat Penelitian dan Pengembangan Hasil Hutan dan Sosial Ekonomi Kehutanan, Badan Litbang Kehutanan, Bogor.

Lenne, J., and D. Wood. 1999. Optimizing Biodiversity for Productive Agriculture. In: Agrobiodiversity: Characterization, Utilization and Management. Wood, D. and J. Lenne (edt.). Wallingford: CABI Publishing. $\mathrm{p}$ : 447-470.

Nair, P.K.R. 1993. An Introduction to Agroforestry. Kluwer Academic Publishers, Dordrecht.

Obiri, B.D., G.A. Bright, M.A. McDonald, L.C.N. Anglaaere, and J. Cobbina. 2007. Financial Analysis of Shaded Cocoa in Ghana. Agroforestry System, 71: 139-149.

Perfecto, I., R. Rice, R. Greenberg, and M. Van der Voort. 1996. Shade Coffee: a Disappearing Refuge for Biodiversity. BioScience, 46: 598-608.

Purseglove, J. 1968. Tropical Crops: Dicotyledons. Longman, Harlow.

Siregar, T.H.S., S. Riyadi, dan L. Nuraeni. 2007. Cokelat: Pembudidayaan, Pengolahan, Pemasaran. Penebar Swadaya, Jakarta. 
Suharjito, D. 2002. Pemilihan Jenis Tanaman Kebun-Talun: Suatu Kajian Pengambilan Keputusan oleh Petani. Manajemen Hutan Tropika, 8(2): 47-56.

Snelder, D.J., M. Klein, and S.H.G. Schuren. 2007. Farmers Preferences, Uncertainties and Opportunities in Fruit-Tree Cultivation in

Diterima : 18 Oktober 2007

\section{Indra Gumay Febriyano}

Staf Pengajar Program Studi Kehutanan

Fakultas Pertanian Universitas Lampung, Lampung
Northeast Luzon. Agroforestry Systems, 71: 1-17.

Thrupp, L.A. 1998. Cultivating Diversity: Agrobiodiversity and Food Security. World Resources Institute, Washington DC.

Young, A. 1989. Agroforestry for Soil Conservation. CABI Publishing, Wallingford. 